\title{
Total knowledge? Encyclopedic handbooks in the twentieth-century chemical and life sciences
}

\author{
Mathias Grote* \\ Institut für Geschichtswissenschaften, Unter den Linden 6, 10099 Berlin, Germany \\ *Email: mathias.grote@hu-berlin.de
}

\begin{abstract}
Encyclopedic handbooks have been household names to scientists - Gmelins Handbuch der anorganischen Chemie to chemists, Bergey's Manual of Determinative Bacteriology to microbiologists. Their heavy tomes were consulted for reference, and their contents taken as authoritative. This paper analyses the development of this genre as well as of 'handbook science'. Handbooks and their claim to provide comprehensive factual knowledge on a subject should be understood as a reaction to the scattering of knowledge in modern periodical print as discussed by Wilhelm Ostwald or Ludwik Fleck. A comparative analysis of the actors, the institutions and practices of compiling and editing a German and an American handbook project around mid-century reveals commonalities and differences in how twentieth-century sciences have attempted to cope with the acceleration and dispersion of knowledge generation before computing. These attempts have resulted in different conceptions of a book, from compilation to organic whole. Moreover, the handbook's claim to comprise lasting facts makes it a fitting case in point to reflect on the temporality of knowledge and the relevance of books to the sciences.
\end{abstract}

In 2018, the shelves dedicated to displaying Gmelins Handbuch der anorganischen Chemie in a science reference section at Berlin's Staatsbibliothek at Potsdamer Platz were cleared. The hundreds of heavy tomes of this register of inorganic chemistry (detailing the names, properties and uses of thousands of substances) were on their way to the depot. In tune with a general library reorganization trend in times of digitalization, the Gmelin as a book was no longer to be consulted on the shelf, making way for users in front of computers. Thereby, the library belatedly responded to a transformation that the Gmelin publishing project had initiated decades earlier by turning this 'bible' for inorganic chemists step-by-step from print to database, ultimately to discontinue altogether the printed version, which had seen eight editions since 1817. Learning by the book, or so it seems, has become a thing of the past, in times when learning by the click is omnipresent (Figure 1).

The production and usage of reference literature, from dictionaries to encyclopedias or handbooks, are seeing dramatic changes in times of wikis and apps. ${ }^{1}$ These current changes to the quotidian, but crucial, practice of looking up factual knowledge provide the historiographical background for this paper. The decline of media that were integral

1 Oliver Jungen, ‘Die Kapitulation des Brockhaus', Zeitschrift für Ideengeschichte (2016) 10, pp. 5-16.

(C) The Author(s), 2020. Published by Cambridge University Press on behalf of British Society for the History of Science. This is an Open Access article, distributed under the terms of the Creative Commons Attribution-NonCommercial-NoDerivatives licence (http://creativecommons.org/licenses/by-nc-nd/4.0/), which permits non-commercial re-use, distribution, and reproduction in any medium, provided the original work is unaltered and is properly cited. The written permission of Cambridge University Press must be obtained for commercial re-use or in order to create a derivative work. 


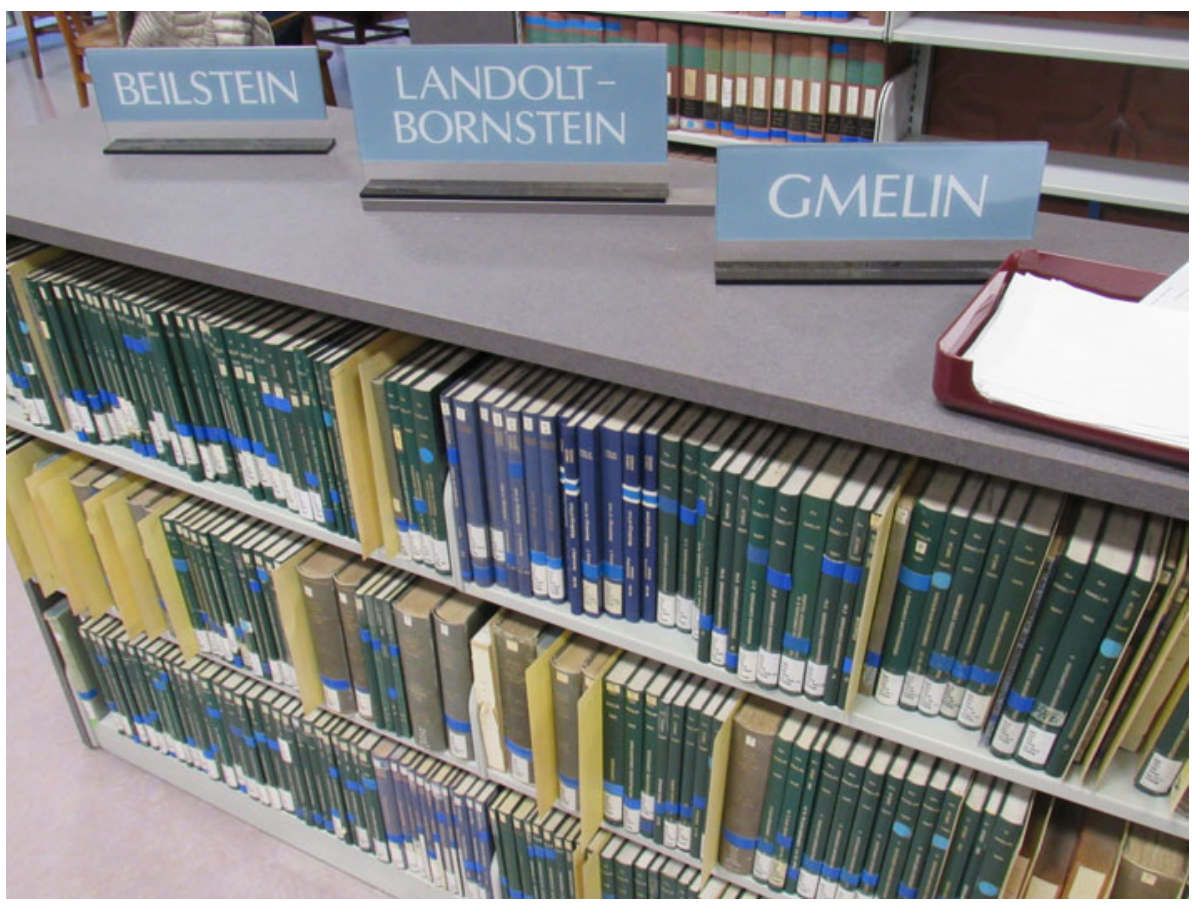

Figure I. Still there: chemistry handbooks in the reference section of the Chemistry and Chemical Engineering Library, University of California at Berkeley, spring 2020. Photograph: M.G.

parts also of offices or laboratories makes pertinent the historical question of the emergence and the production of modern scientific reference literature in print. And even if the 'handbook' as a label indicating factual knowledge remains around online, in many cases it seems that the making and the function of texts claiming to contain reliable and durable knowledge have significantly changed. Put differently: understanding the scientific handbook as a past solution to problems caused by the generation of knowledge during the print era may be informative for the digital age with its own problems of acceleration and dispersion. The question of a canon seems obvious.

Setting out on insights into German-language science handbooks since the nineteenth century, this article will follow their history alongside examples of two encyclopedic reference works of twentieth-century inorganic chemistry (Gmelin) and bacteriology (Bergey's Manual). These books and their making, which can be called, per Ludwik Fleck, 'handbook science', will be studied by looking at visible and invisible actors involved, before turning to an investigation of the practices of moulding scattered article knowledge into books that claim to comprise authoritative knowledge. The problems of such claims with respect to the inflation and outdating of knowledge especially after 1945 form a conceptual axis along which to understand the development of the handbook as a tool for reference. Thus a history of the modern encyclopedic handbook may permit us not only to re-evaluate the role of books in twentieth-century science, but also to reflect on the temporality of facts.

\section{The encyclopedic handbook}

As discussed in the introduction to this issue, there is evidence that the term 'handbook' acquired the specific meaning of an unhandy reference medium in the course of the 
nineteenth century. Such books are called 'encyclopedic handbooks' in the following, as they claimed to present comprehensive, systematically ordered knowledge. This latter was bound to a discipline and mostly not ordered alphabetically, as in dictionaries. ${ }^{2}$ While the formation of this genre of scientific books has to remain open here, the function of encyclopedic handbooks within the development of scientific literature shall be briefly sketched. In English, French and German publishing, the first half of the nineteenth century was characterized by the emergence of scientific journals in the modern sense. To these periodicals, one may add other open-ended formats such as data collection projects or expedition reports that gained traction over the century. All these can be understood as articulations of seriality. ${ }^{3}$

Currentness and 'morselization' (A. Csiszar) of knowledge in serial print, however, were linked to its ageing and dispersion. Several strategies to cope with this syndrome of modernity were developed, such as indices and catalogues of publications, yearbooks or abstract journals (Zentralblätter in German). Yet while these provided merely additive collations of knowledge, the reference handbook claimed to regroup 'atomized' knowledge into a systematically structured and clearly delineated whole.

A case in point is Leopold Gmelin's Handbuch der theoretischen Chemie (first edn, three volumes, 1817-19). This book was to present and reference the properties and uses of known chemical substances, which were rapidly increasing at the time. In other words, Gmelin sought a 'complete, objective presentation of the prevailing state of chemistry'. The purpose of this ordered survey of metals, organic substances and so on was academic pedagogy, by serving as a complement to Gmelin's chemistry lectures. ${ }^{5}$

The handbook as an encyclopedia of a discipline, intended to cope with the amount, the dispersion and the outdating of periodical knowledge, found a contemporary theorizer in the German physical chemist, science organizer and prolific editor Wilhelm Ostwald (1853-1932). His Handbuch der theoretischen Chemie comprises an extensive review

2 On forms of encyclopedism see Ann Blair, Too Much to Know: Managing Scholarly Information before the Modern Age, New Haven, CT: Yale University Press, 2010; Ulrich Johannes Schneider, Die Erfindung des allgemeinen Wissens: Enzyklopädisches Schreiben im Zeitalter der Aufklärung, Berlin: Akademie Verlag, 2013; Helmut Zedelmaier, Bibliotheca universalis und Bibliotheca selecta: Das Problem der Ordnung des gelehrten Wissens in der frühen Neuzeit, Cologne: Böhlau, 1992. The genealogy of handbooks and the encyclopedic tradition especially of the early modern period are complex. While early modern works such as those of Diderot and d'Alembert certainly mark a different genre, in the German-speaking countries lectures attempting to cover a subject in its entirety were also called Enzyklopädie. This title was sometimes carried over into corresponding books, while others were termed 'handbooks'. See Ulrich Dierse, Enzyklopädie: Zur Geschichte eines philosophischen und wissenschaftstheoretischen Begriffs, Bonn: Bouvier, 1977.

3 On journals see Alex Csiszar, The Scientific Journal: Authorship and the Politics of Knowledge in the Nineteenth Century, Chicago: The University of Chicago Press, 2018; Christoph Meinel (ed.), Fachschrifttum, Bibliothek und Naturwissenschaft im 19. und 20. Jahrhundert, Wiesbaden: Harrasowitz, 1997. On collection projects see Lorraine Daston, 'The immortal archive: nineteenth-century science imagines the future', in Daston (ed.), Science in the Archives: Pasts, Presents, Futures, Chicago: The University of Chicago Press, 2017, pp. 159-84. On expedition reports see Lynn Nyhart, 'Voyaging and the scientific expedition report', in Rima D. Apple, Gregory J. Downey and Stephen L. Vaughn (eds.), Science in Print: Essays on the History of Science and the Culture of Print, Madison: University of Wisconsin Press, 2012, pp. 65-86. On the relation to books see James A. Secord. 'Science, technology and mathematics', in David McKitterick (ed.), The Cambridge History of the Book in Britain, Cambridge: Cambridge University Press, 2009, pp. 443-74. On seriality see Nick Hopwood, Simon Schaffer and Jim Secord, 'Seriality and scientific objects in the nineteenth century', History of Science (2010) 48, pp. 251-85.

4 Claude K. Deischer, 'Leopold Gmelin', in Charles C. Gillispie (ed.), Dictionary of Scientific Biography, vol. 5, New York: Scribner, 1981, pp. 429-31, 430.

5 The subtitle of Gmelin's 1817 edition reads, 'zum Behuf seiner Vorlesungen entworfen' ('conceived for the purpose of his lectures'); Leopold Gmelin and Gmelin-Institut (eds.), Handbuch der Theoretischen Chemie, vol. 1, Weinheim: Verlag Chemie, 1817, facsimile edn 1967). On the history of Gmelin see Heinz Götze, Der Springer-Verlag: Stationen seiner Geschichte, vol. 2, Berlin and New York: Springer, 1994, pp. 55 ff. 
of the 'organizational foundations according to which a science is, on the one hand, generated, on the other ordered, taught and distributed'. 6 I will dwell on his analyses, which have to be considered in the context of his attempts to reform scientific publishing, not to give a somewhat idiosyncratic chemist power of definition. Yet Ostwald's text is a rare moment in which a scientist carefully observes and reflects on the printed matter encountered in daily work. In contemporary parlance, Ostwald provided a history and sociology of chemistry's media.

Ostwald recognized in Gmelin's first edition the archetype (Urbild) of the chemical handbook, characterized as a 'most conveniently manageable reference book for the scientific worker'. ${ }^{7}$ Which brings us to the issue of handbook versus textbook, or practice and pedagogy: Michael Gordin has shown for another influential chemistry handbook, Beilsteins Handbuch der organischen Chemie (first edition 1881-3), that this has resulted from a textbook project turned into reference work. ${ }^{8}$ Thus both Gmelin and Beilstein seem to display a genealogy intertwining pedagogy and practice, with textbook and handbook being interconnected genres that appear more clearly differentiated by the end of the century. ${ }^{9}$ To Ostwald, it seemed by then obvious that the handbook was used by practitioners (or at least experienced students), and that it could, therefore, present its subjects in a systematic rather than a pedagogical order. Further hallmarks of this genre mentioned by the Leipzig chemist were a depersonalized perspective as a reporter (Berichterstatter), and the extracting and referencing of primary literature in a precise (genau) and exhaustive (erschöpfend) manner. ${ }^{10}$

The twentieth-century concept of the handbook as sketched by Ostwald makes it appear a manifestation of a modern take on knowledge as composed of objective facts in pieces. These could be gathered in large, cooperative projects, which encompassed not only such books but also archival or filing projects, some of which set out to standardize formats or language. ${ }^{11}$ Needless to say, this conception of a book and the knowledge therein also found its critics: in his sneer at the nineteenth century's positivist understanding of history, Friedrich Nietzsche used his readers' associations of handbooks

6 Wilhelm Ostwald, Handbuch der allgemeinen Chemie: Die Chemische Literatur und die Organisation der Wissenschaft, Leipzig: Akademische Verlagsgesellschaft, 1919, vol. 1, Vorwort: 'Es handelt sich um die allgemeinen organisatorischen Grundsätze, nach denen eine Wissenschaft einerseits erzeugt, andererseits geordnet gelehrt und verbreitet wird.' On Ostwald's initiatives to reform scientific publishing see e.g. Markus Krajewski, Zettelwirtschaft: Die Geburt der Kartei aus dem Geiste der Bibliothek, Berlin: Kadmos, 2006; Michael Gordin, Scientific Babel: How Science Was Done before and after Global English, Chicago: The University of Chicago Press, 2015. On the question of 'genre' in the twentieth century see Alrun Schmidtke, 'The handbook as genre: conflicting concepts in 1950s physics publishing', History of Knowledge, 31 May 2018, at https://historyofknowledge.net/2018/05/31/the-handbook-as-genre (accessed 1 July 2020).

7 Ostwald, op. cit. (6), p. 51: 'als möglichst bequem handhabbares Nachschlagebuch für den wissenschaftlichen Arbeiter'.

8 The Beilstein contained a systematically ordered inventory of organic chemical substances, which had been covered by the Gmelin before the explosion of carbon-based synthetic chemistry. See Michael Gordin, 'Beilstein unbound: the pedagogical unravelings of a man and his Handbuch', in David Kaiser (ed.), Pedagogy and the Practice of Science: Historical and Contemporary Perspectives (Inside Technology), Cambridge, MA: MIT Press, 2005, pp. 11-40. On these and other compendia in organic chemistry see also Evan Hepler-Smith, 'Nominally rational: systematic nomenclature and the structure of organic chemistry, 1889-1940', PhD dissertation, Princeton University, 2016.

9 To go deeper into this matter, one would have to take into account changes in how chemistry was taught as well as practised as a profession. On self-teaching in nineteenth-century physics manuals see Kathryn Olesko, 'The foundations of a canon: Kohlrausch's practical physics', in Kaiser, op. cit. (8), pp. 323-56; on pedagogy more generally see Kaiser, op. cit. (8).

10 Ostwald, op. cit. (6), pp. 51-2.

11 Krajewski, op. cit. (6); Gordin, op. cit. (6). On encyclopedic projects in the late nineteenth and early twentieth centuries see W. Boyd Rayward (ed.), European Modernism and the Information Society: Informing the Present, Understanding the Past, Aldershot: Ashgate, 2008. 
to scoff at modern Bildung and Wissenschaft. To him, such books represented an unaesthetic and unoriginal form of knowledge - they were made for epistemic 'barbarians', and turned their fact-stuffed users into 'walking encyclopedias'. ${ }^{12}$

The most concise characterization of the reference handbook's function within modern science was provided by Ludwik Fleck. His Development and Genesis of a Scientific Fact outlined the Handbuchwissenschaft, i.e. science of or within the handbook, as an intrinsic part of the modern scientific thought collective, along with journals, textbooks and popular science. Fleck characterized the handbook as the medium where the provisional, fragmentary and personal knowledge published in articles was transformed into impersonal, collective and fixed facts (Tatsachen). ${ }^{13}$ He goes as far as to stipulate that facts in the sense of fixed or proven knowledge were to be found exclusively in the context of handbook science, while journal science would comprise their disposition (Anlage). ${ }^{14}$ Thus obtaining handbook knowledge involved not merely a sequential collation of articles, but their 'critical summary into an ordered system', or even an 'organic whole' - his analogy being the composition of a mosaic from its parts. ${ }^{15}$ It is this process - crucial, according to Fleck that this paper will examine.

When browsing through twentieth-century encyclopedic handbooks, one gets the impression that very different books bore this label on their covers, and that naming has often been influenced by custom, marketing or personal preferences. Also, specimens that match the characteristics mentioned above have been designated compendium, Grundriss (outline) or treatise/traité (e.g. by Belgian documentation pioneer Paul Otlet). While the boundaries between handbooks and textbooks or lexicographic projects remain permeable, it makes sense to distinguish encyclopedic handbooks as a genre. ${ }^{16}$ This latter is characterized by an intended function as reference work for practitioners, as well as by a systematic order of contents (as opposed to alphabetical or pedagogical), by references to primary literature and by an ideal of comprehensiveness or completeness. Differences pertain to the textual forms used to present knowledge: some handbooks were composed of longer articles in prose up to monograph length, while others contained shorter texts, often written in a codified or abbreviated style (of course, these forms are not mutually exclusive).

Prose handbooks were what Fleck had in mind: The Handbuch der pathogenen Mikroorganismen that he took as inspiration comprised review-like articles written by different authors which attempted to cover medical bacteriology as it had developed since the late nineteenth century (e.g. concepts, topics, technique, history). ${ }^{17}$ As a work summarizing, but also actively shaping, the discipline, this handbook not only was a

12 Friedrich Nietzsche, 'Vom Nutzen und Nachteil der Historie für das Leben', in Nietzsche, Die Geburt der Tragödie, Unzeitgemäße Betrachtungen I-IV, Nachgelassene Schriften 1870-73, vol. 1 (ed. KSA, G. Colli and M. Montinari), Munich: Deutscher Taschenbuch Verlag, 1988, p. 274: 'wandelnde Encyclopädien', 'Handbuch der inneren Bildung für äußere Barbaren'. Nietzsche seems to make no difference between encyclopedias and handbooks here.

13 Ludwik Fleck, Entstehung und Entwicklung einer wissenschaftlichen Tatsache: Einführung in die Lehre vom Denkstil und Denkkollektiv, Frankfurt am Main: Suhrkamp, 1980 (first published 1935), pp. $146 \mathrm{ff}$. The English translation of Fleck's Handbuchwissenschaft into 'vademecum science' (vademecum being a small, often personalized, book) fits less well than 'handbook science' (both are mentioned).

14 Fleck, op. cit. (13), p. 164.

15 Fleck, op. cit. (13), pp. 156, 158.

16 Paul Otlet, Traité de documentation: Le livre sur le livre, Brussels: Editiones Mundaneum, 1934, lemma 241.2, 'Traités. Manuels', pp. 129 ff.; Evan J. Crane, Austin M. Patterson and Eleanor B. Marr, A Guide to the Literature of Chemistry, New York: John Wiley, 1957, p. 14. For a perspective from library and cultural studies see Ulrich J. Schneider, 'Handbuch', in Ute Frietsch and Jörg Rogge (eds.), Über die Praxis des kulturwissenschaftlichen Arbeitens: Ein Handwörterbuch, Bielefeld: transcript, 2013, pp. 179-83.

17 Wilhelm Kolle, August Wasserman et al. (eds.), Handbuch der pathogenen Mikroorganismen, Jena: Fischer, 1st edn, 4 vols., 1902-4; 2nd edn, 8 vols., 1912-13; 3rd edn, 10 vols., 1928-31. 
repository of facts but epitomized the discipline's 'thought style'. ${ }^{18}$ Prose handbooks as extensive, synthetic pictures of a field or discipline often shared the arrangement of texts or editor- and authorship with collected volumes (Sammelband); however, they had a very different, foundational claim.

Handbooks containing lemmata, tables or data overlapped with shorter manuals, but also with specialized dictionaries. ${ }^{19}$ Yet whereas the latter presented their subjects mostly in alphabetical order, handbooks displayed a systematic order and thereby suggested comprehensiveness.

\section{Inventories of their disciplines: Bergey's Manual and Gmelins Handbuch}

When the first edition of Bergey's Manual of Determinative Bacteriology was published in 1923, work on the eighth edition of Gmelins Handbuch der anorganischen Chemie had just begun, with the overall Gmelin project being six years past its centenary (Figure 2; a digitized version of Bergey's 1957 edition can be consulted at the Internet Archive; historical volumes of Gmelin's eighth edition are found at SpringerLink). A comparative analysis of these inventories of chemical substances or microbial species is valuable as both acquired comparable roles: they became central, internationally used reference works to look up and find properties of the objects of either microbiology or inorganic chemistry - sometimes termed the 'bibles' of their fields. ${ }^{20}$ If researchers wanted to know the properties of a microbe they had come across, or if they were to check for the properties of a chemical substance, they would likely consult Bergey's or Gmelin. And yet it is probably safe to reiterate for these books what Michael Gordin has stated for Beilstein: their names would be known to pretty much every scientist without their authors being famous. In fact, many handbooks survived their creators and were continued across political or epistemic ruptures, with their content taken as prescriptive for other texts. Similar to technological infrastructures, handbooks were as omnipresent as they were invisible. ${ }^{21}$

The importance of Bergey's and Gmelin for their fields, as much as the high amount of labour and organizational continuity needed to entertain them, correlates with their proximity to institutions. While Bergey's had initially resulted from efforts of the

18 There are numerous other examples of prose handbooks that were to become or have become canonical for their disciplines, both in the sciences and in the humanities, e.g. the Handbuch der Physik (after 1945 Encyclopedia of Physics), Schmidtke, op. cit. (6). A history of the Berlin science publisher Springer, an important player in the handbook business, named more than twenty-five projects begun or carried out between 1924 and 1933, comprising more than three hundred volumes. See Heinz Sarkowski, Springer-Verlag: Stationen seiner Geschichte I (1842-1945), Heidelberg: Springer, 1992, pp. 258-9. An example for the Handbuchkultur of the humanities is discussed by Stefan Rebenich, C.H. Beck. 1763-2013. Der kulturwissenschaftliche Verlag und seine Geschichte, Munich: Beck, 2013, pp. 209-41. On the relation of handbook to modern scientific encyclopedias see Dorien Daling, 'The encyclopedia as pioneer of the journal: the early years of Elsevier's Scientific Publishing Company, 19361956', in Marieke van Delft, Frank de Glas and Jeroen Salman (eds.), New Perspectives in Book History: Contributions from the Low Countries, Zutphen: Walburg Pers, 2006, pp. 31-48.

19 For an early example containing data and tables that has been re-edited many times see Wilhelm Ostwald's Hand- und Hilfsbuch zur Ausführung physicochemischer Messungen, Leipzig: Engelmann, 1893. On specialized dictionaries in pharmacology see Karl Conrath, Pharmazeutische Wissenswelten: Lexika der Pharmazie des 'langen' 19. Jahrhunderts als Spiegelbild eines Wandels von der 'techne' zur 'scientia', Stuttgart: Wissenschaftliche Verlagsgesellschaft, 2017.

20 On Gmelin as 'the bible of industry of our century', see e.g. Otto Sroka, 'Das Gmelin-Kloster im Oberharz', Die Zeit, 10 February 1949, 6 (translation M.G.); Lynn Margulis termed Bergey's 1957 edition 'that bible of microbiology'. See Lynn Margulis, 'Origin and evolution of the eukaryotic cell', Taxon (1974) 23, pp. 225-6, 226. https:// www.zeit.de/1949/06/das-gmelin-kloster-im-oberharz.

21 On Beilstein see Gordin, op. cit. (8). On 'information infrastructures' in classification see Geoffrey C. Bowker and Susan L. Star, Sorting Things Out: Classification and Its Consequences, Cambridge, MA: MIT Press, 1999. 


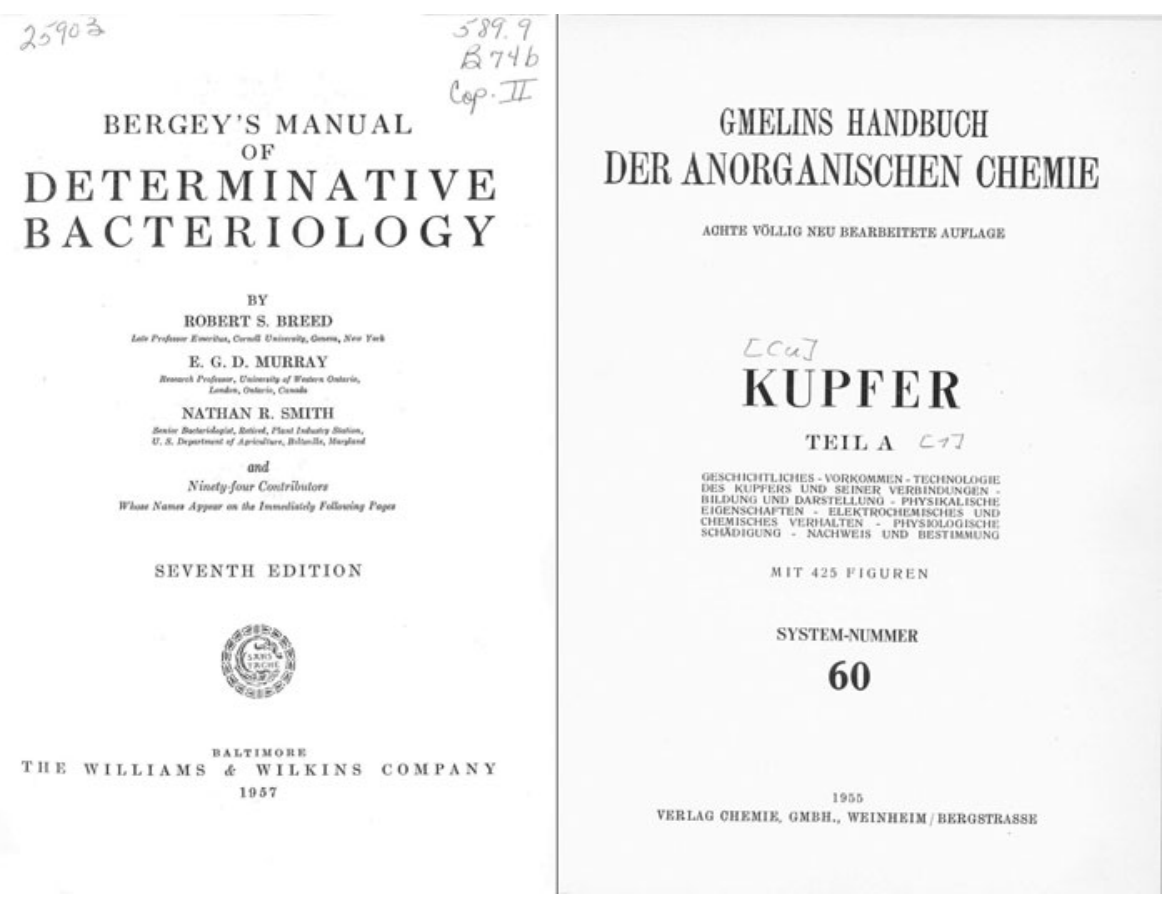

Figure 2. Title pages of Bergey's Manual and Gmelins Handbuch (a volume on copper, indicating the element's number in the 'Gmelin system', p. 8). Note the differences regarding authorship.

Society of American Bacteriologists ( $\mathrm{SAB}$ ) to reign in taxonomic and nomenclatural confusion of bacteriology after 1900, the book project was carried out from the 1930s by a trust. This latter, using sales revenues to finance work on the next edition, was formed by experts in bacterial taxonomy and found its headquarters at different universities throughout the US, later on also abroad. ${ }^{22}$ Gmelin's eighth edition was edited by an office connected to the Deutsche Chemische Gesellschaft (German Chemical Society) from the 1920s until the end of the Second World War. After 1945, a Gmelin-Institut (GMI) was created as part of the Max Planck Society (MPG).

While Gmelin changed its language from German to English step by step in the post-war decades (e.g. by introducing bilingual tables of contents, headings and paratexts), Bergey's became translated into Russian and Chinese in this period. ${ }^{23}$ Moving rapidly beyond their national contexts of origin, both book projects became global in coverage and international in audience.

In the period of observation, roughly from the 1930s to the 1960s, Bergey's and Gmelin were ever-growing collaborative projects of writing and editing scientists, who used index cards as tools to extract, store and order textual knowledge. While these paper-based recording techniques were increasingly mechanized after 1945, e.g. through punched cards, it is important to stress that the developments described here took place before personal computing. ${ }^{24}$

22 On the development of Bergey's from discussions among the SAB see Eric D. Kupferberg, 'The expertise of germs: practice, language and authority in American bacteriology, 1899-1924', PhD dissertation, MIT, 2001; for an overview of Bergey's history from within see Robert G.E. Murray and John G. Holt, 'The history of Bergey's manual', in Bergey's Manual of Systematics of Archaea and Bacteria, vol. 20, London: Wiley, 2015, pp. 1-20.

23 Murray and Holt, op. cit. (22).

24 Krajewski, op. cit. (6). 
Yet there are important differences between the book histories of Gmelin and Bergey's: The latter started as a portable manual (one volume, roughly quarto format, 461 pages) and in so far represented something like a microbiological 'lab guide', with each species represented by a short entry. Bergey's more than doubled in page number through five re-editions until the 1950s, and it was later accompanied by other publications, such as a name index or a journal. While Bergey's seven one-volume editions until 1974 were titled 'determinative', referring to the work's original instructional function, the trust then decided to publish a large four-volume 'systematic' library book, containing introductory essays, longer articles, tables and images. ${ }^{25}$ This change was accompanied by the publication of abridged editions with reduced information and a layout for benchtop use (spiral binding, soft cover). ${ }^{26}$ This split represented more than the creation of a new product: as the minutes of the trust meetings document, the separation of manual and systematic handbook reflected both a crisis caused by an increasing amount of information, and a change of the trust's claim regarding taxonomy. While the determinative book referred to an admittedly conventional order of organisms for the purpose of identification, the systematic one implied a taxonomically sound classification. ${ }^{27}$ The development of Bergey's from determinative manual to systematic handbook runs parallel to a sea change in microbial taxonomy, which was plagued by rivalling approaches until the rise of molecular taxonomy in the 1970 s. $^{28}$ The term 'manual', however, has been kept in its title to date - presumably since the book had meanwhile become a brand.

The entangled history of a book and its (sub)discipline looks completely different for Gmelin and inorganic chemistry: the chemical order of elements, represented by the periodic table, was not a matter of discussion after 1920, and the number of new elements added remained small compared to microbial species. While Gmelin does not reflect changing taxonomies of chemical elements, the project was also faced with a steeply increasing amount of information, i.e. a continuously increasing number of substances as well as of information on their properties, usages and so on. This is mirrored in the tragic fact that its eighth edition, begun in 1925 with completion expected within a decade, was finished only shortly before the millennium. This edition comprised one or more volumes for each element and its compounds. However, neither the order of volumes nor their sequence of publication concurred with the arrangement of elements displayed in the periodic table (e.g. the hydrogen volume was not number 1, or published first). To unambiguously place the vast amount of compound substances, such as table salt, the book followed the so-called 'Gmelin system', according to which each element was matched with a number (differing from that in the periodic table). A compound would always be listed with the element of the highest system number - as chlorine was 6 and sodium was 21 , table salt was located in a sodium volume. This helped to evenly distribute and list

25 Earlier the new name was 'descriptive bacteriology'. The new book was announced at a trust meeting as a 'storehouse of information and a reference', while the determinative work should be 'useful at the bench', and the abridged version was a 'cut and paste effort'. Minutes of Bergey's Manual Trust (BMT), New Orleans, 6 May 1977, Williamsburg, VA, 19 September 1986, private collection. Thanks to Barny Whitman, Athens, GA, for digitized minutes of the trust meetings, which are of great historical value. See also Murray and Holt, op. cit. (22).

26 On the one hand, these changes could be read as the development of a 'scientific brand'; on the other, they also mirror the transformation of bacterial systematics from being largely part of medical diagnostics, practised in an ad hoc way, into a specialized and highly codified research field based on taxonomic principles.

27 The BMT minutes quoted a critique of Russian researchers, who perceived the new Bergey's as too expensive and 'encyclopedic rather than determinative'. Minutes of BMT, op. cit. (25), Niagara-on-the-Lake meeting, 27 September 1988.

$28 \mathrm{Keep}$ in mind that the specificity of bacterial reproduction (clonal lines), evolution (DNA sequences as taxonomic characters) or heredity (lateral gene transfer) found widely accepted molecular explanations only after 1970. Jan Sapp, 'The bacterium's place in nature', in Sapp (ed.), Microbial Phylogeny and Evolution: Concepts and Controversies, Oxford: Oxford University Press, 2005, pp. 3-53. 
composites according to some degree of chemical analogy, e.g. as sodium salts (all halogens had lower numbers than metals). In the sequence of publishing, this giant book project of more than seven hundred volumes forms a rhizomatic structure that grew simultaneously in different places, added to by supplements or reprints.

Thus not only was Gmelin a much larger project than Bergey's, but its eighth edition temporally straddled all seven of the latter's, rendering volumes from the late 1920s still 'operative' when they were clearly outdated. Differences also related to price, audience and sold copies: Bergey's was marketed to individuals and scientific libraries through a medium-sized American science and medicine publisher, while Gmelin was sold in far smaller numbers through a subscription model and primarily targeted academic institutions or companies. In other words, Bergey's, written and edited by regular university scientists, represented a commercially viable science book. Gmelin, by contrast, resembled an infrastructure project, the costs of which (full-time employees) were defrayed less through sales than by societies, donations and the German state. $^{29}$

\section{Microbe philologists and literature chemists: handbook scientists}

The making of both Bergey's and Gmelin was organized by specific actors who deserve scrutiny since they deviate from the received picture of how scientists and their assistants worked in the last century. A figure with formative influence on Bergey's from the 1920 s to the 1970s was Robert E. Buchanan (1883-1973) from the University of Iowa at Ames, a largely agricultural institution. ${ }^{30}$

Buchanan's place of work seems to have been not so much the laboratory as the library. After studying botany at Ames and obtaining a bacteriology degree in Chicago, he returned to Iowa in 1910, becoming the first professor of the newly established field there. He was elected president of the SAB in 1918 and turned the small mid-western college into a focal point of agricultural microbiology. Although Buchanan carried out experimental work, his six-hundred-page monograph published in 1925 appears as a taxonomic compendium compiling and criticizing literature. ${ }^{31}$ These interests and work style were to prevail when Buchanan started to engage with Bergey's - his preferred tools being index cards and filing cabinets instead of pipettes and Petri dishes. Moreover, he built up a large reprint collection on bacterial nomenclature associated with the trust's office. ${ }^{32}$

29 While in the 1930s copies of Bergey's sold per edition by Williams \& Wilkins of Baltimore ranged in the thousands, these rose to 40,000 for the eighth edition (1974); Murray and Holt, op. cit. (22), p. 8. Subscriptions for the entire Gmelin by the Verlag Chemie ranged in the hundreds (e.g. 150 for the US) in 1955, although single volumes were also marketed. Thomas Hapke, 'Erich Pietsch: international connections of a German pioneer in information science', in W. Boyd Rayward and Mary E. Bowden (eds.), The History and Heritage of Scientific and Technological Information Systems: Proceedings from the 2002 Conference, Philadelphia: Chemical Heritage Foundation, 2004, pp. 327-38.

30 The life and character of Robert S. Breed (1877-1956), microbiologist at the Agricultural Experiment Station at Geneva, NY, who served as first chairman of the trust from 1937 to 1956 (i.e. a year after the latter had been formed, following the death of its founder, hygienist David H. Bergey), resembles that of Buchanan on many counts.

31 The book includes long quotations from primary literature or compilations of foreign texts. Robert E. Buchanan, General Systematic Bacteriology: History, Nomenclature, Groups of Bacteria, Baltimore: Williams \& Wilkins, 1925; Rivers Singleton Jr, 'Robert Earle Buchanan: an unappreciated scientist', Yale Journal of Biology and Medicine (1999) 72, pp. 329-39.

32 The preface to the Index Bergeyana mentions a collection of fifteen thousand 'reprints, photostats and manuscripts'. Robert E. Buchanan, John Holt and Erwin Lessel, Index Bergeyana, Baltimore: Williams \& Wilkins, 1962, p. vi. 
During Buchanan's tenure as chairman of the trust, a central and long-standing project was the compilation of an index comprising all Latin and vernacular names given to bacteria since the start date of legitimate botanical nomenclature in 1753 (publication of Linnaeus's Species Plantarum). Presumably in analogy to the Index Kewensis, a cumulative index of plant names, this latter was baptized Index Bergeyana. ${ }^{33}$

Interlibrary-loan slips document the breadth of literature research required to track down the origin, meaning, validity and references of nomenclature, some as far back as the eighteenth century. ${ }^{34}$ Buchanan seems to have known German; however, as a college newspaper had it, he learned Latin from his college football coach. ${ }^{35}$ Consequently, much of the reading and excerpting seems to have been carried out by assistants. The extent and character of this division of labour can only be gleaned from isolated records: a photograph in a 1958 university newspaper shows Buchanan in front of a card catalogue filling an entire wall. Seated next to him is an elderly woman searching index cards in wooden drawers. Elza Zvirbulis, a 'Latvian refugee' and 'expert on foreign languages including Russian, Greek and Latin', seems to have maintained this paper database of more than ten thousand bacterial names. ${ }^{36}$ Thus the practice of handbook science, demanding skills that were not among those taught or valued in bacteriology, seems to have relied not only on particular leading figures but on less visible actors as well. Many of these were female and may have occupied roles similar to laboratory technicians. ${ }^{37}$

Buchanan vigorously defended the relevance of exactness and breadth of linguistic knowledge in public, for example when he demanded 'microbiological literacy' from his colleagues. ${ }^{38}$ Whereas nomenclature appeared arbitrary even to other systematists, who thought of names as mere 'tags' attached to the classificatory categories, this microbe philologist considered Babylonian confusion a fatal error of science. One obituary makes Buchanan indeed sound more like a humanist than a scientist: "In his love for Latin and Greek, and of the etymology of names, Buchanan was a microbiologist extraordinary. ${ }^{39}$

These interests and characterization tie in with the significance attributed to historiography in Bergey's: The first edition set out a chronological summary of prior classification schemes of microbes back to the early nineteenth century; that is, long before Pasteur and Koch. This was neither hagiography nor critique - the chronology summarizing 'outdated' classification schemes allowed systematists to trace back the origin of nomenclature to determine its legitimacy.

Even as Buchanan became a quintessential senior professor, spending decades on the etymology of bugs' names in a small mid-western university, he and those surrounding him, in fact, represent 'unappreciated scientist[s]', as another obituary had it, not least

33 Buchanan, Holt and Lessel, op. cit. (32). Note that Bergey's also echoed a book title from microbiology's often overlooked disciplinary antecedent - Gray's Manual, started by Harvard botanist Asa Gray as a guide to the plants of the northern United States, became a re-edited classic text.

34 Interlibrary-loan slips, Buchanan Papers, Iowa State University Archives, Ames, IA.

35 Anonymous, 'He looks to the future', News from Iowa State, 1965, p. 1; also Samuel T. Cowan, 'Robert E. Buchanan: obituary', Journal of General Microbiology (1973) 77, pp. 1-4.

36 Newspaper clipping, 'ISU edits bacteriology manuals', probably from Iowa State Daily, R.E. Buchanan Papers, Box 1, Folder 2, 'Biographical continued', Iowa State University Archives, Ames.

37 Steven Shapin, 'The invisible technician', American Scientist (1989) 77, pp. 554-63. Zvirbulis signed as a co-author of at least two publications inquiring into the status of nomenclature on the basis of extensive research in taxonomic literature of the nineteenth century. Buchanan also co-authored a successful book with his wife, botanist Estelle D. Fogel.

38 Robert E. Buchanan, 'Microbiological literacy', Bacteriological Reviews (1958) 22, pp. 204-15.

39 Cowan, op. cit. (35). See the analogous characterization of earlier handbook scientists. Matthias Dörries, 'Heinrich Kayser as philologist of physics', Historical Studies in the Physical and Biological Sciences (1995) 26, pp. 1-33. 
for the historiography of science. In addition to his contributions to documentation, he became a figure of scientific diplomacy. His textual skills and experiences from an astonishing number of committees and international meetings were certainly helpful in such undertakings: after the Second World War, for example, he was sent to the Middle East and Greece on a mission of the UN Food and Agriculture Program.

These activities also allow us to get a glimpse of Buchanan's political convictions. On his Greek mission, he was quoted in 1965 that it 'had a good deal to do with the final elimination of Communism' from the country. His fierce rejection of allegations of US involvement in biological warfare in Korea, which had been addressed to him as a delegate to the International Congresses of Microbiology by the Polish society (signed, among others, by Fleck), speaks a similar language. Buchanan repeatedly insisted on scientific freedom in America and the need for evidence and objectivity - very much in line with Audra Wolfe's interpretation of such rhetoric as a strategy of American science and government in the exchange across the Iron Curtain. ${ }^{40}$

Buchanan's work style and the slow pace of his scientific life contrast starkly with the narrative of the experimental life sciences at the time. A point of comparison is the new molecular biology, much of which drew on microbes, and which was characterized by speedy discoveries and actors moving between topics and places. One of these, Roger Y. Stanier, perceived handbook science as old-fashioned and provincial, suggesting abandoning the revision of Bergey's for the next edition and reshaping the trust as a coordinating centre for interdisciplinary experimental work. This was never to happen, however. ${ }^{41}$

The scientific life of the German chemist Erich H.E. Pietsch (1902-79), the long-time head of Gmelin, differs on many counts from that of Buchanan. However, there are several structural similarities in terms of scope and work style that may help to characterize the figure of the handbook scientist in more detail. After his $\mathrm{PhD}$ and experimental work on inorganic catalysis, Pietsch became part of the group embarking on Gmelin's eighth edition in the mid-1920s, then at the German Chemical Society's Berlin office. He advanced in the hierarchy of staff members, in 1936 following Jewish rare-earth expert Richard Joseph Meyer (1865-1939) as editor-in-chief. ${ }^{42}$

One initiative started at the Gmelin office under Pietsch's directorship was the collection of sources, and the setting up of an index card catalogue on the history of chemistry modelled on George Sarton's example. What is more, the Gmelin devoted an entire volume to the history of each element, presenting source materials and detailing technological uses in different cultures from prehistorical times up to around 1800. Drawing on data from archaeology and prehistory, Gmelin aimed to provide a holistic picture (Gesamtschau) of the roles materials had played in the longue durée of 'cultures', described in an essentializing and stereotyped fashion. ${ }^{43}$

40 Anonymous, op. cit. (35), p. 2; Buchanan Papers, Box 1, Folder 2, Biographical continued, letter, Polskie Towarzystwo Mikrobiologów to Buchanan, 4 May 1952; also Box, 69 Folder 1, Correspondence Polish Microbiological Society, letter, R.E. Buchanan and C.H. Werkman to L. Hirszfeld, 9 May 1952, Iowa State University Archives, Ames; Audra J. Wolfe, Freedom's Laboratory: The Cold War Struggle for the Soul of Science, Baltimore: Johns Hopkins University Press, 2018.

41 Minutes of BMT, op. cit. (25), Chicago meeting, 5 December 1965; on file cabinets see BMT Minutes, New Orleans, 6 May 1977; on lives in molecular biology see Horace F. Judson, The Eighth Day of Creation: Makers of the Revolution in Biology, expanded edn, Cold Spring Harbor: Cold Spring Harbor Laboratory Press, 1996; on Stanier see Susan B. Spath, 'Cornelis Bernardus Van Niel and the culture of microbiology, 1920-1965', PhD dissertation, University of California, 1999.

42 Malte Stöcken, Dokumentation der Chemie in Krieg und Frieden, Bochum: Klartext, 2017, pp. 52 f.

43 Erich Pietsch, 'Sinn und Aufgaben der Geschichte der Chemie', Angewandte Chemie (1937) 51, pp. 939-48; Helmut Maier, Chemiker im Dritten Reich, Weinheim: Wiley, 2015, pp. 315 ff.; Pietsch also wrote a monograph on the early modern chemist Johann Rudolf Glauber. 
A more mundane motivation for pursuing chemistry's history was to highlight its potentials for autarky, and in fact Pietsch became deeply involved in science politics of the Third Reich, e.g. by tapping money from the chemical industry to fund work on the handbook. ${ }^{44}$ During the Second World War, he was stationed in occupied Eastern Europe, directing the pillaging of scientific resources. In a particularly gruesome episode, he had concentration camp inmates transported westwards, to deploy them as forced labour probably also for the handbook project. While the Gmelin library and card index were lost in 1943 bombings, a microfilm duplicate preserved the pre-war work. ${ }^{45}$

According to anecdote, nuclear chemist Glenn T. Seaborg had relied on Gmelin's uranium volume during the Manhattan project as a source of information. Whether this is true or not, the handbook's knowledge was certainly considered of economic and strategic importance by numerous actors - to wit, microfilm copies of the original Gmelin material had been confiscated by American officers. ${ }^{46}$ After May 1945, Pietsch seems to have changed sides rapidly, and, negotiating with representatives of the Western Allies and the Kaiser Wilhelm Society, he and staff travelled to the British zone, where a makeshift institute was opened in 1946. The relevance of the information may also explain why Pietsch and the institute fared so well, why both rose to prominence in the 1950s (the institute had a New York office) and why Pietsch was able to cooperate closely with international experts on documentation in the ensuing decades. In 1957, the GMI, then part of the MPG, became the official site for documentation on nuclear energy in the Federal Republic of Germany, furnishing literature such as the US Atomic Energy Commission's reports. Under Pietsch's directorship, the institute grew, employing numerous technological and clerical assistants; moved to a modern new building in Frankfurt; and became involved in mechanizing and automating scientific documentation. ${ }^{47}$ It was in this context that Pietsch used the term of a Fachmann für Literaturchemie ('expert in literature chemistry') to describe the professional handbook scientist employed at the GMI. ${ }^{48}$

Comparing Buchanan and Pietsch, the continuity of their book work and the fact that this became the dominant aspect of their scientific biography are striking. Moreover, both shared an interest in text and information rather than in experimentation, thereby resembling natural historians of prior periods. Yet it seems premature to simply dismiss microbe philologists or literature chemists as adjunct, peripheral or outmoded. Looking closer at their projects brings actors to the fore that often go unnoticed - women, minority groups or scientists at the periphery. ${ }^{49}$ The entangled histories of collecting, naming and classifying, and the production of handbooks, but also grey literature, reveal that these figures were no less important than their experimenting counterparts. In addition to the information infrastructures they provided, their roles in communication, documentation technology and politics indicate that the handbook scientists' relative invisibility

44 Stöcken, op. cit. (42); Erich Pietsch, 'Physik und Chemie als Überwinder deutscher Rohstoffarmut', in Dt. Akademie München (ed.), Wissenschaft im Lebenskampf des deutschen Volkes, 1941, pp. 73-98.

45 Stöcken, op. cit. (42), Chapters 12, 16.

46 Stöcken, op. cit. (42), Chapter 21; for the Seaborg anecdote see D. Stein, 'Zur Gmelin-Arbeit in den USA', in Alfons Kotowski (ed.), Dokumentation im Gmelin-Institut: Erich Pietsch zu seinem 60. Geburtstag von seinen Mitarbeitern, Frankfurt am Main: Gmelin-Institut, 1962.

47 Pietsch was assisted by his deputy since pre-war times, Alfons Kotowski. Kotowski, op. cit. (46).

48 On the Fachmann für Literaturchemie see Erich Pietsch, 'Neue Methoden zur Erfassung des exakten Wissens in Naturwissenschaft und Technik: Zur Krisis auf dem Gebiet der Dokumentation des wissenschaftlichen und technischen Schrifttums', Nachrichten für Dokumentation (1951) 2, pp. 38-44, 39; the term 'literature chemist' had been used by documentation specialist James W. Perry slightly earlier. James W. Perry, 'The literature chemist', Chemical and Engineering News (1950) 28, pp. 4530-2.

49 E.g. Jewish scientists employed at the Beilstein office before 1933. Hepler-Smith, op. cit. (8), pp. 6, 180. Or Margaret O. Dayhoff, who worked on an atlas of protein structures. Bruno J. Strasser, Collecting Experiments: Making Big Data Biology, Chicago: The University of Chicago Press, 2019, Chapter 3. 
may, not least, be a historiographical problem. Put differently, practices of archiving, reading, translating and systematizing text appear not as residues of a style of knowledge production that pre-date experimental science, but as complementary to innovation and the accumulation of novelty. ${ }^{50}$

\section{Handbook science in practice: work at the Gmelin Institute, 1945-1960s}

Insight into the details of how encyclopedic handbooks were compiled and written is difficult: while publishers' archives frequently contain business correspondence only, the personal papers of involved scientists rarely provide much insight either. What is more, editorial offices often moved around. ${ }^{51}$ By contrast, the archival records of the GMI after 1945 provide a rare opportunity to understand how the editing of a large handbook project was carried out. The GMI represented a special case due to its centralized organization and full-time staff, turning it into something like an information service. While technological facilities differed from less professionalized and more distributed projects such as Bergey's, one may assume that general principles of paperwork in the era of the index card have been similar.

Under Pietsch's direction, labour at the GMI was organized hierarchically: so-called Hauptredakteure (head editors) planned and organized the volumes on each element, while Fachredakteure, the next-lower level, revised the texts, which in turn seem to have been compiled by Manuskriptbearbeiter (Figure 3). This organization reflected Pietsch's aim to produce a 'monolithic' work, in which, as a report put it, the personality of each staff member had to stand back to serve the idea of the handbook. ${ }^{52}$ The book as an organic whole, as opposed to an additive compilation, clearly echoed a vitalist leitmotiv of pre-war German scientific discourse. ${ }^{53}$ In fact, the idea of totalizing bodies of knowledge seems to have been widespread. ${ }^{54}$ Pietsch, however, continued this rhetoric well after 1945, thereby expressing an authoritarian concept of work and authorship. The 'book as a whole' reflected what the Gmelin was to achieve culturally: the head editor borrowed the idea of a transdisciplinary cultural synthesis (Zusammenschau or Kulturschau) from amateur historian Oswald Spengler, notorious for his Decline of the West (1918/22). If this romanticizing concept of knowledge was trumpeted as the aim of a mundane reference book, it strikes as even more ironic that he recommended quintessentially mechanical means, such as punched cards, to get there. ${ }^{55}$

Memos or an instructional manual for GMI staff document several measures on how literature review and the extraction of the relevant data to obtain a homogeneous

50 Lorraine Daston, 'The sciences of the archive', Osiris (2012) 27, pp. 156-87; Nicholas Jardine, James A. Secord and Emma C. Spary (eds.), Cultures of Natural History, Cambridge: Cambridge University Press, 2004.

51 Bergey's trust office, for example, moved around between the home institutions of its heads, with many documents being discarded. Email, John Holt to author, 21 January 2017.

52 GMI papers, AMPG II. Abt. Rep. 38 A 169-1 Tätigkeitsberichte, p. 7: 'Der Arbeitsstab des Instituts bietet durch die 'räumliche und zeitliche Zusammenarbeit aller Kräfte die Gewähr für eine restlose Abstimmung des Materials und für eine einsinnige Aufgabenstellung des gesamten Mitarbeiterstabes, in dem Sinne, daß, soweit es irgend angängig ist, das Werk wie aus einem Guß geschrieben erscheint, wobei die Persönlichkeit jedes einzelnen Mitarbeiters letzten Endes zurückzutreten hat; jeder einzelne Mitarbeiter hat der Idee des Handbuchs voll zu dienen'. Original underlining.

53 Anne Harrington, Reenchanted Science: Holism in German Culture from Wilhelm II to Hitler, Princeton, NJ: Princeton University Press, 1996.

54 Such as in Emil Abderhalden's Handbuch der biologischen Arbeitsmethoden, Berlin and Vienna, 1921-39 - a gigantic project (more than a hundred volumes), trying to bring together methods from branches of science researching 'life' in the broadest possible sense.

55 E. Pietsch, 'Wie ist eine große Dokumentationsstelle für die Fachgebiete der Naturwissenschaften aufzubauen?', Nachrichten für Dokumentation (1951) 2, pp. 116-24 

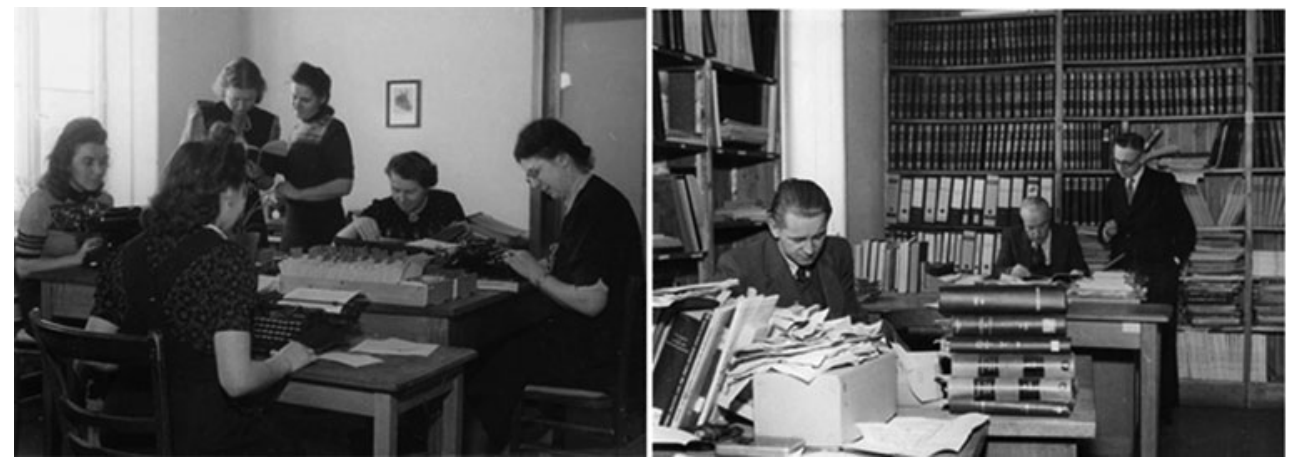

Figure 3. 'Experts in literature chemistry'. Laboratory at the Gmelin-Institut, presumably 1950s. Female staff in the picture on the left were unnamed, those on the right are identified as employed chemists holding diplomas or PhD degrees in the original image caption. The institute seems to have employed female chemists as well as clerical assistants throughout its existence. Source: Archives of the Max Planck Society, Berlin-Dahlem. Reproduced with permission.

work were to be achieved. Even a manual to instruct employees on the proper way of making a handbook was published. ${ }^{56}$ Among more formal measures to secure homogeneity was a periodization of literature analysis (Literaturperiode), setting a start and end date mentioned on the volume's title page. Moreover, the selection of covered literature pertaining, for example, to languages or thematic scope seems to have been continuously redetermined.

An album presented to Pietsch on the occasion of his thirtieth anniversary in the project represents the most detailed source on the daily routines of the GMI. ${ }^{57}$ Containing images and actual index cards, the album details a process that started with reading articles or Chemical Abstracts, the now-dominant American abstract journal. ${ }^{58}$ The centrepiece of the GMI was its Kartei, a collection of handwritten and typed index cards containing abbreviated knowledge, supplemented with references and keywords for the creation of thematic collections. However, the album also shows how photomechanical reproduction and machines for automated thematic sorting of punched cards on a certain subject were adopted to 'rationalize' work.

Based on these insights into how the Gmelin was made, it is interesting to note the differences to the redaction of Bergey's: in contrast to the hierarchically organized, monolithic Gmelin, the Americans pursued much more of a distributed, pragmatic approach to bringing the scattered and evolving knowledge on bacteria between the covers of a book. This pertains to the order of contents, but equally to the organization of work: trustees served as experts in different areas, who acquired texts from specialized outside scientists. These were listed as co-authors. Thus Bergey's appears as a book project with less defined boundaries and with a concept of authorship that came closer to what was generally practised in twentieth-century sciences. In consequence, Bergey's was more of a variegated compilation than a monolithic synthesis.

After isolation and loss due to the war, the GMI seems to have caught up with the status quo of chemistry after 1945 with astonishing speed, not least aided by donations

56 Gmelin-Institut (ed.), Vorschriften für die Mitarbeiter am Gmelin-Handbuch für anorganische Chemie, brochure without place/date, AMPG Library.

57 Album, 'Die Dokumentation der anorganischen Chemie im Gmelin-Institut', 1 April 1955, Pietsch Papers, AMPG III. Abt., Rep. 22, Nr. 13.

58 Hepler-Smith, op. cit. (8), Chapter 6 
from the American Chemical Society and the International Union of Pure and Applied Chemistry. A decade later, the project was faced by an ever-increasing and faster-ageing amount of literature. ${ }^{59}$ Even a well-equipped institute such as this could not keep up; there were complaints about volumes being outdated upon publication, or lacking significant new information due to a literature deadline too far back. Generally, a desynchronization of the project was felt as certain areas (e.g. semiconductor compounds) developed at a greater speed than others. ${ }^{60}$ In the early 1960s, when Derek de Solla Price's Little Science, Big Science illustrated the exponential growth of contributions in Chemical Abstracts, even the more than a hundred scientific and technical staff of the GMI, adding 200,000 new index cards annually to the two million existing, could not keep track with the perceived literature deluge. ${ }^{61}$ Suggestions were voiced to abandon the Gmelin style of descriptions in full sentences in favour of an annotated bibliography. The institute adopted a reform programme, which tried to assess the problem by estimating an average rate of 'information ageing' to determine when supplements would be due (remember that all volumes produced since the 1920 s were technically part of the same edition). ${ }^{62}$

Bergey's seems to have been faced with similar problems at the time - its eighth edition (1974) had an extensive time lag of seventeen years from its predecessor, while molecular biology had dramatically changed microbiological knowledge during these years. ${ }^{63}$ As different as these two book projects were in their organization, both resorted to similar solutions, such as the publication of yearbooks or supplements on certain subjects as 'stopgaps' to get relevant information out before it had been moulded into its more durable handbook form.

To sum up, the encyclopedic handbook as a comprehensive and critical survey of knowledge, let alone Pietsch's holistic idea of a book covering a subject homogeneously, was becoming increasingly unfeasible after 1960. In fact, many handbooks already represented something like a periodical from a publishing point of view, as the appearance of volumes or brochure-like parts over decades had 'serialized' them. However, both Gmelin and Bergey's began to actually disintegrate as books at this time, moving towards an ensemble of provisional and sometimes open-ended formats. The GMI reacted to this also by offering an on-demand information service, the Gmelin Informationsdienst, that supplied specific 'raw' data in the form of reproduced index cards. ${ }^{64}$

It is beyond the scope of this article to discuss the developments that affected both books after 1970, such as uses of computing, digital publishing or changes of publisher (Gmelin contracted with Springer in 1973, Bergey's in 1998; in both cases, one reason mentioned was more funding). ${ }^{65}$ While the deluge and accelerated production of periodical literature were factors challenging the science of the handbook, it remains to be studied how far digital technologies, changes in the publishing sector or in the reputation of handbook

59 Erich Pietsch, 'Gmelin-Institut für anorganische Chemie', Jahrbuch der Max-Planck-Gesellschaft zur Förderung der Wissenschaften e.V. (1961) 2, pp. 339-68.

60 Gmelin's American representative, Dimitri Stein, worried about the reputation and status of Gmelin among US scientists because of the outdatedness of 'new' volumes. Letter, Dimitri Stein to Erich Pietsch, 21 September 1959, AMPG III. Abt., Rep. 22, Nr. 40.

61 The term used in a memo of the committee on the Reformprogramm was Literaturflut. AMPG II. Abt., Rep. 66, Nr. 38A 817-1 'Zum Gmelin-Reformprogramm', 20 November 1967, p. 8; see also a newspaper article, W. Möbus, 'Zweihunderttausend Karten im Jahr', Der Tagesspiegel, 8 April 1962, from newspaper clipping in the same archival collection, Nr. 1355 Bd 1/2 1960-65.

62 'Zum Gmelin-Reformprogramm', op. cit. (61); Stein to Pietsch, op. cit. (60).

63 On the abridged edition see Minutes of BMT, op. cit. (25), New Orleans, 6 May 1977. The delay was also due to Buchanan's high age. He stayed editor-in-chief until his death in 1973, aged ninety.

64 Rudolf Warncke, 'Der Informationsdienst des Gmelin-Instituts', in Kotowski, op. cit. (46), pp. 83-5.

65 Murray and Holt, op. cit. (22), p. 12; Götze, op. cit. (5), p. 55. 
science and the willingness to fund long-term infrastructure projects have affected such undertakings.

\section{Conclusion: books and the temporality of modern scientific knowledge}

What is an encyclopedic handbook? As this history of two central twentieth-century cases has shown, scientific reference literature was not particularly handy, and therefore should be distinguished from smaller, instructional manuals, despite all vicissitudes of judging books by their names. Looking at the plethora of encyclopedic handbooks from the sciences and the humanities, and taking into account Ostwald's and Fleck's reflections, the handbook can be described as a medium of scientific modernity that claimed to comprise canonical or 'core' knowledge of a discipline from journal articles in a comprehensive, objective, referenced and critical way. ${ }^{66}$ While I argue that it is possible to distinguish such handbooks as a genre, it has also become clear that different concepts of the book have been articulated for different handbooks, ranging from a monolithic synthesis in the case of Gmelin to a more flexible and open format for Bergey's.

This article has mainly focused on how such heavy tomes were compiled, looking at the actors and practices of handbook science. This latter, like much information infrastructure and generally modern encyclopedism in print, appears undervalued by both scientists and scholars of science. ${ }^{67}$ Yet it might be worth attention in times when digitalization and commodification are dramatically reshaping essential information resources. ${ }^{68}$ Even if actors such as those from Bergey's or Gmelin remained far from science's frontier of novelty and fame, and at least in Pietsch's case are politically repulsive, they cannot be considered unproductive - as scientists at the periphery, as compilers, bores or fossils. The encyclopedic handbook conveyed a type of knowledge deemed crucial by many practitioners, institutions and the state, as well as profitable to publishers.

The work style of the handbook scientists, characterized by a continuity of time and place, and a focus on textual practice rather than experimentation, highlights the ongoing relevance of natural-historical working and thinking in biology and chemistry. This reinforces the insight that a turn from natural history to experimentation as the grand narrative of modern biology does not grasp the full picture. Collecting and classifying remained important also in the experimental sciences, and rose to prominence again with the creation of large databases in the late twentieth century. ${ }^{69}$ The history of handbook sciences adds to this by highlighting the relevance of textual practices carried out by microbe philologists and literature chemists. Thereby, handbooks not only subvert the boundary between natural history looking backwards in time and forward-looking experimentation, but also reveal a double bind between these two aspects of modern science's temporality. This was perceived already by Fleck, who added to his characterization of handbook knowledge that the latter was, as a scientist knew full well, 'inevitably already out of date' ('immer bereits überholt').

Thus the handbook reveals itself a paradoxical medium of scientific modernity: due to the long periods of time needed to work out an ordered system of knowledge in a

66 As discussed in the introduction, the formation of the modern reference handbook concurs with the surge of what Lorraine Daston and Peter Galison have characterized as 'mechanical objectivity' for observation practices and styles of pictorial representation. Lorraine Daston and Peter Galison, Objectivity, New York: Zone Books, 2007. Olesko, op. cit. (9), has analysed the making of a canon for a continuously re-edited physics text.

67 On the textbook tradition see Kaiser, op. cit. (8).

68 Michael Hagner, Zur Sache des Buches, Göttingen: Wallstein, 2015.

69 Strasser, op. cit. (49).

70 Fleck, op. cit. (13), p. 164, translated as 'out of date' in the English edition. The original term for 'outdated' was überholt. 
book format intended to last, the handbook lagged behind an ever-faster-moving and differentiating frontier of research. One may understand this paradox as resulting from a particular experience of acceleration, the consequences of which were reflected famously by Max Weber: to be überholt (outdated) was not only the fate of a scientific existence but its end. ${ }^{71}$ However, there is a second meaning to this very term in German, which moves beyond Weber's sobering diagnosis and epitomizes the handbook's contribution to science. Überholt does not only mean outdated but also overhauled, in the sense of being maintained, kept or taken care of, e.g. for a technical device. As this paper has shown, overhauling knowledge was exactly what the handbook was about. This may also explain the historical consciousness of many handbook scientists, ranging from source collections to surveys to historiography. ${ }^{72}$ Taking overhaul and maintenance seriously, modern handbooks and maybe bookish media generally should not be conceived as mere appendices of scientific literature.

A narrative of monolithic and omnipresent acceleration of knowledge output and publication still dominates the picture of twentieth-century sciences. Following up what David Edgerton has stated about technology, one has to concede that also large parts of the history of science appear to be written for boys of all ages. ${ }^{73}$ By contrast, the handbook produces a specific 'shock of the old' for scientific modernity: as a heavy, immobile and therefore untimely medium with its proper, slower temporality, it serves as a reminder that acceleration and dispersion of knowledge in bits and pieces represent only one end of the spectrum of putting science into print. In fact, the handbook should be understood as a counterstrategy to cope with this specific effect: working against time, handbook projects attempted to reassemble morselized knowledge, thereby often suffering undeserved fates - the laments of tireless editors, shortages of money and the plethora of projects that have remained giant stubs bear testimony to this tragedy of the handbook.

In the libraries of our digital present, library shelves are freed of the metres of heavy tomes that promised a core of established knowledge: Gmelin is continued in the form of Elsevier's Reaxys database, while Bergey's current edition is marketed through the Springer website. Databases and digital publishing may have rendered reference literature handy in yet another sense, yet they also significantly reconfigure access, usage, editing and revision. Returning to the intricate connection that Fleck stipulated between the handbook's heavy print and the scientific facts of his age, the role of books and encyclopedism in science deserves more attention in our times.

Acknowledgements. I would like to thank the participants of the Learning by the Book conference at Princeton, those of the writing workshop at the MPI for the History of Science in Berlin, and those of various colloquia and meetings, for stimulating discussions on prior versions of this article. Anna-Maria Meister (Darmstadt) and Evan Hepler-Smith (Durham, NC) provided very valuable suggestions. The Archives of the Max Planck Society Berlin are acknowledged for permission to reproduce images.

71 Max Weber, 'Wissenschaft als Beruf', in Weber, Gesammelte Werke, vol. 17, Tübingen: Mohr Siebeck, 1992, pp. 582-613, 592: 'Wissenschaftlich aber überholt zu werden, ist - es sei wiederholt - nicht nur unser aller Schicksal, sondern unser Zweck'.

72 Cf. Hepler-Smith, op. cit. (8), p. 200.

73 David Edgerton, The Shock of the Old: Technology and Global History since 1900, London: Profile Books, 2006.

Cite this article: Grote M (2020). Total knowledge? Encyclopedic handbooks in the twentieth-century chemical and life sciences. BJHS Themes 5, 187-203. https://doi.org/10.1017/bjt.2020.11 